Science and Humanities Journal 14:1-15 (2020)

DOl: https://doi.org/10.47773/shj.1998.141.1

\title{
Morphological Characterization of Native Pigs (Sus scrofa domesticus L.) in Bohol Province, Philippines
}

$\overline{\text { Ronel B. Geromo }}^{1 *}$, Dinah M. Espina ${ }^{1}$, Milagros C. Bales ${ }^{2}$, and Masahide Nishibori ${ }^{3}$

\begin{abstract}
This study assessed the morphological characteristics of the native pig population in Bohol Island, Philippines. A total of 100 sexually-mature native pigs (80\% gilt/sow and $20 \%$ barrow/boar) were selected from the municipalities of Balilihan, Bilar, Talibon, Ubay, Loon, Guindulman, Mabini, San Miguel, Pilar, and Alburquerque, which are densely populated with native pigs (based on the data of the Office of the Provincial Veterinarian-Bohol). Purposive sampling was used to select the experimental pigs based on the phenotypic traits that qualify them as native. Likewise, remote barangays where native pigs are most likely raised were selected as sample sites. The qualitative (hair color, color pattern, and ear orientation) and quantitative (tail length, teat number, estimated body weight using body length, and heart girth measurements) traits were recorded based on subjective observation and actual measurements, respectively. Qualitatively, the native pigs in Bohol have predominantly (73\%) black hair. In terms of color pattern, plain color $(91 \%)$, spotted $(4 \%)$, and patchy $(5 \%)$ were noted. The native pigs also revealed droopy (54\%), slightly droopy (37\%), and erect (9\%) ear orientations. Meanwhile, quantitative traits revealed an overall body length of $38.07 \pm 8.75$ inches, heart girth of $36.9 \pm 8.83$ inches, body weight of $67.29 \pm 41.15 \mathrm{~kg}$, tail length of $9.78 \pm 2.45$ inches, and $12.38 \pm 1.33$ number of teats. Significant differences across sampling areas $(p<0.05)$ and sex $(p<0.01)$ were observed. Generally, females had higher values than males, and there was a significant difference $(p<0.05)$ in trait values among age groups.
\end{abstract}

Keywords: native pig, morphology, Bohol

\section{INTRODUCTION}

Raising native pigs has a good potential in the agricultural production system in the rural areas of the Philippines. In terms of business opportunities, it is a good prospect for small industry players while also preserving and further developing the native pig breeds in the country. These indigenous pig populations also perform other functions, in support of the cultural, social, and economic status of rural

${ }^{1}$ Department of Animal Science, Visayas State University, Visca, Baybay City, Leyte, Philippines

${ }^{2}$ Department of Agricultural Extension and Education, Visayas State University, Visca, Baybay City, Leyte, Philippines

${ }^{3}$ Graduate School of Biosphere Science, Hiroshima University, 1-4-4 Kagamiyama, Higashi-Hiroshima 739-8528, Japan

*Corresponding Author : Address: Department of Animal Science, Visayas State University, Visca, Baybay City, Leyte, Philippines. E-mail: ronel.geromo@vsu.edu.ph 
farming communities. More importantly, these have higher disease resistance, excellent adaptation to the environment, unique texture and taste of meat, and require minimal material and technological inputs (Jeong et al 2014). The increasing global population drives the demand for meat production, leading to intensive farming which makes use of commercial breeds and hybrids. However, people nowadays are becoming more health conscious, and they choose natural products in the organic farming sector.

The decreasing ratio of these indigenous breeds in the country due to commercialization has led researchers to improve their production performance and product quality without reducing genetic diversity. Basically, native animals depend on their unique phenotypic and genetic characteristics to adapt to their environment and the conditions of small-scale farms. Their existence is also influenced by their ability to produce products with attributes that are preferred and paid for with a premium price by consumers. However, the success in the conservation and use of native animals largely depend on the identification and development of their unique characteristics (Food and Fertilizer Technology Center for Asian And Pacific Region 2017). The thorough understanding of the characteristics and identification of the unique traits of native breeds are necessary to address the needs of farmers in their decision-making on livestock development and breeding programs, to meet the demands of consumers and protect the environment. Concurrently, the evaluation of the phenotypic variation among native pig populations is important to identify their uniqueness and the possible gene flow between populations (Subalani et al 2011). The native pigs of Bohol are an important genetic resource which is continually upgraded or replaced by highly productive and generally imported breeds resulting in the displacement of these locally-adapted indigenous pigs. Although some studies were conducted on the origin and genetic diversity of pigs in some countries in East Asia, morphological data and genetic information of native pigs in the Philippines, specifically in Bohol Province is insufficient and not fully documented. Hence, this study was conducted to evaluate and identify the morphological traits of the native pigs in the Province of Bohol, Philippines.

\section{MATERIALS AND METHODS}

\section{Experimental Animals and Study Sites}

A total of 100 sexually-mature native pigs were purposively selected from 10 municipalities of Bohol Province, Philippines which are densely populated with native pigs (based on the data of the Office of the Provincial VeterinarianBohol).These included the municipalities of Balilihan, Bilar, Talibon, Ubay, Loon, Guindulman, Mabini, San Miguel, Pilar, and Alburquerque.

The purposive sampling method used to select the pigs was based on the phenotypic traits that qualify them as native. Based on the analysis of simple statistical modes, the native pig is often described as predominantly black in color, has a long face, long snout, short and low-set body conformation, and erect ears. Standard characteristics of "native" pig breeds or strains versus "improved native" pigs are still lacking. Therefore, minimum standards must be set and certified initially in order to conserve the true "native" pigs. Likewise, remote barangay in each 


\section{Morphological Characterization of Native Pigs in Bohol, Philippines}

municipality where native pigs are most likely raised were selected as sample sites. Ten sample pigs from one grower/raiser in each municipality were selected.

\section{DATA COLLECTION}

The data for the phenotypic characterization of native pigs were based on the guidelines set by the Food and Agriculture Organization (2012). The qualitative (hair color, color pattern, and ear orientation) and quantitative (tail length, teat number, body length, heart girth, and estimated body weight) traits were collected based on visual observation and actual measurements, respectively. The data gathered were recorded using a data sheet.

The teats were counted to obtain the number of teats per animal. A tape measure was used to get the body length (measured along the arc of the back from the poll point midway between the ears to the base of the tail), chest/heart girth (by placing the tape measure behind the front legs, wrapped snugly and measure the circumference), and tail length (measured from the base of the tail to the tip). The quantitative traits were measured in each pig sample, except for the body weight which was estimated using the following formula (Javier 2001):

$$
\frac{\text { Heart girth }^{2} \text { (inch) } \times \text { body length (inch) }}{400}=\frac{\text { Body Weight (pounds) }}{2.2}=B W(\mathrm{~kg})
$$

This formula is accurate within 3\% (PigSite 2002) and has been cited by the Canadian Journal of Animal Science. However, it was used to estimate body weights of modern pigs, thus results may vary to the actual body weight.

\section{Statistical Analysis}

The qualitative traits were analyzed for descriptive statistics using frequency procedures of STATA version 14.2. Data on age, tail length, number of teats, body length, heart girth, and body weight were analyzed using Kruskal-Wallis and Post Hoc Tests to test the difference of the morphological characteristics across sampling areas and age groups, while Wilcoxon Rank Sum Test was used to determine differences by sex.

\section{RESULTS AND DISCUSSION}

\section{Qualitative Traits}

\section{Hair and Coat Color}

Majority (66\%) of the pig samples were classified as adult (9 months and above), while a little over a third (34\%) were young (below 9 months). Based on actual and subjective observation, $73 \%$ of the native pig samples in Bohol were black-colored including one wild pig collected in Bilar, Bohol (Figure 1 and Appendix Figure 2). The remaining sample population (27\%) have other color characteristics (Figure 2 and Appendix Figure 2). Table 1 shows that black color was highest (100\%) in the municipality of Ubay followed by Loon and Pilar (90\%); Alburquerque, Mabini and Talibon (80\%); Guindulman and San Miguel (60\%); Balilihan 50\%; and Bilar 
(40\%). This coincided with Layos et al (2018) who reported that black color was also predominant among the native pigs of Panay and Guimaras Islands, Philippines. The Philippine Native pig is either black or black with a white belly. There are five strains of native pigs in the Philippines that were under research, documentation, and breeding development. These include: Kaman (native pig in Batangas $x$ Duroc Jersey), Diani (native pig in Batangas $x$ Berkshire), Black llocos (native pig in llocos province $x$ Berkshire or Poland China breeds), Berkjala (native pig in Jalajala, Rizal $x$ Berkshire), and Koronadal (native pig in Cotabato x combination of Poland China, Berkshire, Duroc Jersey)(Penalba 1993).

Table 1 further shows the frequencies of other color variations such as black with white belt and white forelegs, black with white patch on forehead, black with white patches on forehead and face, black with white patches on forehead and foreleg, black with white patches on forehead, abdomen and feet, black with white patches on forelegs, black with white patches on hind legs, black, white and light red, blackish gray, dark red, dark red with black spots, light red, and light red with black spots. In Panay and Guimaras Islands, Philippine native pigs (PNPs) having black with white patches on the abdomen, black with white patches on the abdomen and feet, black with white in feet, black with white on feet and forehead and blackish gray (Layos et al 2018). Mason (1996) confirmed that Philippine native pigs were either totally black or had black-colored bodies with occasionally whitecolored belly and white and red markings.

At the molecular level, the melanocortin 1 receptor (MC1R) gene (a single coding exon of about $950 \mathrm{bp}$ ) plays a key role in melanogenesis for bettercharacterized coat color gene in Sus scrofa. It regulates eumelanin (black/brown) and phaeomelanin (red/yellow) synthesis within the mammalian melanocyte and is encoded by the classical Extension (E) coat color locus. The wild-type state in many species involves synthesis of both melanin types. However, mutations at $E$ locus may commit the melanocyte to exclusive synthesis of a single pigment. In mammals, dominant alleles at Extension act to produce uniform black coat color (Searle 1968; Jackson 1997) whereas recessive alleles at this locus extend the amount of red/yellow pigment. The ED1 allele was suggested to be the major allele controlling the black coat color within local pig breeds(Kijas et al 1998, 2001). MC1R mutations have been shown to alter pigment synthesis resulting to different color variations. Seven MC1R alleles corresponding to four coat color phenotypes have been found in pigs: MC1R1 $(\mathrm{E}+)$ and $M C 1 \mathrm{R}^{\star} 5(\mathrm{E}+)$ for the wild-type color, $M C 1 R \star 2$ (ED1), MC1R*7 (ED1) and MC1R*3 (ED2) for the dominant black, MC1R*6 (EP) associated with black spots on a red or white background, and MC1R*4 (e) influencing the recessive red in European pig breeds.

Dominance of black hair color in native pigs of Bohol Island may also result from less to no systematic process e.g., migration, mutation, and selection of the genetic properties of population (Hardy-Weinberg equilibrium), in which the gene and genotypic frequency of a large random mating population remains constant from generation to generation and potentially reduces the genetic diversity and phenotypic variability. Bohol is an island province, thus introduction of new sets of genomes is limited. The possibilities of mating within population might have occurred. This recurrent admixture had the effect of homogenizing the genomes of native pig populations, which eventually led to the emergence of the typical morphological homozygosity (black hair-colored pigs). Variable traits found in 


\section{Morphological Characterization of Native Pigs in Bohol, Philippines}

domestic animals are the result of relatively recent human-mediated selection. Under farm conditions, there is a selection pressure by the native pig raisers who are forced to select the pure black color as the most important criterion/standard to qualify their stocks as native. Consumers, especially the health-conscious, choose pigs which are considered organically grown. They usually associate this with the black color of the pig's hair and coat.

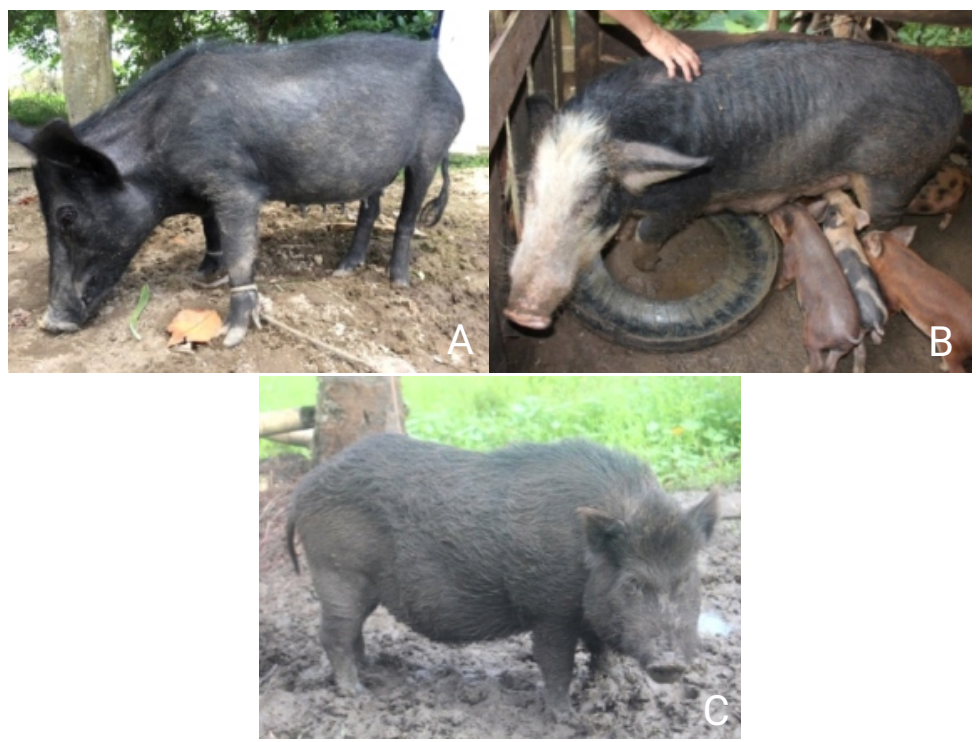

Figure 1. The predominant hair and coat color characteristics of native pigs in Bohol Island, Philippines: black colored (A), black with white patches in the forehead (B), and black of the wild pig (C)
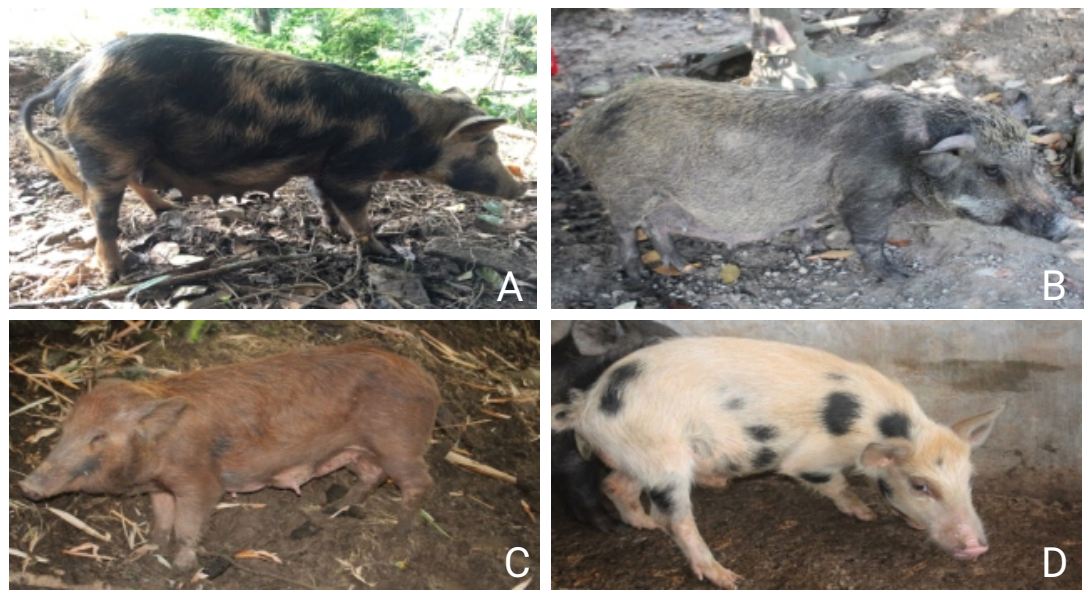

Figure 2. The other color characteristics of native pigs in Bohol Island, Philippines showing black, white and light red (A), blackish gray (B), dark red with black spots (C), and light red with black spots (D) 


\section{Color Pattern}

Table 1 and Figure 3 show that the dominant body coat color pattern of pigs in Bohol Island, Philippines was plain (91\%) and the rest were either patchy $(5 \%)$ or spotted (4\%). It should be noted that the native pigs observed from the municipalities of Loon, Mabini, Pilar, San Miguel, and Ubay showed $100 \%$ plain color pattern. Meanwhile, $4 \%$ of the pigs in the municipalities of Balilihan, Bilar, Guindulman, and Albur had spotted color pattern, and the rest have patchy color pattern distributed in the municipalities of Balilihan (2\%), Talibon (2\%), and Bilar $(1 \%)$. The results partly conformed with the findings of Layos et al (2018) who observed black with patches in the native pigs of Panay and Guimaras Islands, Philippines. Navarra (1996) also documented the phenotype of 19 male and 21 female Philippine native pigs (Sus scrofa L.) and found that black was the predominant coat color pattern (85\%), varying from pure black (40\%), or with white spots on the face, hocks and tail $(32.5 \%)$, or white underline (10\%). Rust-brown (7.5\%) and light brown with black spots (10\%) were also observed.

Mutations in melanocortin 1 receptor (MC1R) gene and v-kit Hardy-Zuckerman 4 feline sarcoma viral oncogene homolog (KIT) gene have been shown to affect coat color patterns in pigs (Klomtong et al 2015). MC1R variants are responsible for the dominant black, black spotted, and red coat colors in both Western and Chinese pigs (Kijas et al 1998, 2001; Fang et al 2009). Multiple alleles for different coat color phenotypes have been identified at the KIT locus, including the recessive wild-type allele $i$, Patch allele $I^{p}$ (Johansson et al 1992), Belt allele $I^{\text {Be }}$ (Giuffra et al 1999), and Roan allele $\mathrm{I}^{\text {Bex }}$ (Pielberg et al 2002).

This study is limited only to the observation of the phenotypic characteristics of native pigs in Bohol, thus molecular differentiation of native pig breeds is still unknown. Mixing local breeds was a common practice with most domesticated animals before either reproductive isolation started or humans began to confine them to protect against extinction and recognize their importance. In the Philippines, native/wild pigs were probably allowed to roam freely in the locality and could have bred with domestic pigs. The gene flow was asymmetrical, basically more modern breed genome flew into the native stock; thus, non-behavioral traits such as color pattern mixture of native and modern pig breeds have been observed.

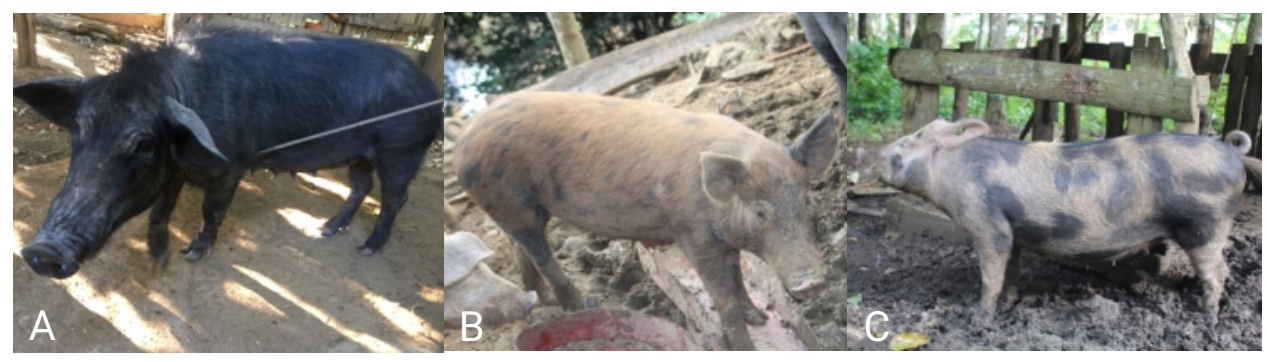

Figure 3. The native pigs in Bohol Island, Philippines showing plain (A), spotted (B), and patchy $(\mathrm{C})$ color patterns 
Table 1. Number of native pigs in Bohol Island, Philippines with varying hair color, color pattern, and ear orientation

Black, white \& light red

Blackish gray

\begin{tabular}{ccccccccccc}
\hline \multicolumn{10}{c}{ SAMPLING SITES } & $\%$ \\
Albur & Balilihan & Bilar & Guindulman & Loon & Mabini & Pilar & San & Talibon & Ubay & TOTAL \\
freq & freq & freq & freq & freq & freq & freq & freq & freq & freq & \\
\hline
\end{tabular}

HAIR COLOR

Black

Black w/ white belt and

0

white forelegs

Black w/ white patch

on forehead

Black w/ white patches

on forehead \& face

on forehead \&

forelegs

Black w/ white patches

on forehead,

abdomen \& feet

Black w/ white patches

on forelegs

Black w/ white patches

on hind legs

Dark red

Dark red w/ black

spots

Light red

Light red w/ black

spots

TOTAL

$\begin{array}{ll}5 & 4 \\ 0 & 1 \\ 0 & 1 \\ 1 & 0 \\ 0 & 1\end{array}$

$\begin{array}{lll}9 & 8 & 9 \\ 1 & 0 & 0 \\ 0 & 1 & 0 \\ 0 & 0 & 0 \\ 0 & 0 & 0\end{array}$

$\begin{array}{llll}6 & 8 & 10 & 73\end{array}$

0

(1)




\begin{tabular}{|c|c|c|c|c|c|c|c|c|c|c|c|}
\hline \multirow[b]{2}{*}{$\begin{array}{c}\text { MORPHOLOGICAL } \\
\text { TRAITS }\end{array}$} & \multicolumn{10}{|c|}{ SAMPLING SITES } & \multirow[b]{2}{*}{$\begin{array}{c}\% \\
\text { TOTAL }\end{array}$} \\
\hline & $\begin{array}{l}\text { Albur } \\
\text { freq }\end{array}$ & $\begin{array}{l}\text { Balilihan } \\
\text { freq }\end{array}$ & $\begin{array}{l}\text { Bilar } \\
\text { freq }\end{array}$ & $\begin{array}{l}\text { Guindulman } \\
\text { freq }\end{array}$ & $\begin{array}{l}\text { Loon } \\
\text { freq }\end{array}$ & $\begin{array}{l}\text { Mabini } \\
\text { freq }\end{array}$ & $\begin{array}{l}\text { Pilar } \\
\text { freq }\end{array}$ & $\begin{array}{c}\text { San } \\
\text { Miguel } \\
\text { freq }\end{array}$ & $\begin{array}{l}\text { Talibon } \\
\text { freq }\end{array}$ & $\begin{array}{l}\text { Ubay } \\
\text { freq }\end{array}$ & \\
\hline \multicolumn{12}{|l|}{ COLOR PATTERN } \\
\hline Plain & 9 & 7 & 8 & 9 & 10 & 10 & 10 & 10 & 8 & 10 & 91 \\
\hline Spotted & 1 & 1 & 1 & 1 & 0 & 0 & 0 & 0 & 0 & 0 & 4 \\
\hline Patchy & 0 & 2 & 1 & 0 & 0 & 0 & 0 & 0 & 2 & 0 & 5 \\
\hline TOTAL & 10 & 10 & 10 & 10 & 10 & 10 & 10 & 10 & 10 & 10 & 100 \\
\hline \multicolumn{12}{|l|}{ EAR ORIENTATION } \\
\hline Droopy & 4 & 4 & 4 & 1 & 6 & 7 & 6 & 9 & 8 & 5 & 54 \\
\hline Slightly droopy & 6 & 3 & 4 & 6 & 4 & 3 & 4 & 1 & 2 & 4 & 37 \\
\hline Erect & 0 & 3 & 2 & 3 & 0 & 0 & 0 & 0 & 0 & 1 & 9 \\
\hline TOTAL & 10 & 10 & 10 & 10 & 10 & 10 & 10 & 10 & 10 & 10 & 100 \\
\hline
\end{tabular}

Table 2. Morphological characteristics of native pigs across sampling areas in Bohol Island, Philippines (Mean \pm STD)

\begin{tabular}{|c|c|c|c|c|c|}
\hline \multirow{2}{*}{ SAMPLING SITES } & \multicolumn{5}{|c|}{ MORPHOLOGICAL TRAITS } \\
\hline & Tail length (inch) & Body Length (inch) & Heart Girth (inch) & Body weight (kg) & No. of teats \\
\hline Alburquerque & $9.25^{\text {bcde }} \pm 2.28$ & $32^{\mathrm{e}} \pm 6.26$ & $30.4^{d} \pm 7.14$ & $37.91^{d} \pm 23.37$ & $11.6^{a} \pm 0.89$ \\
\hline Balilihan & $11.3^{\mathrm{a}} \pm 3.02$ & $41.4^{\mathrm{ab}} \pm 6.05$ & $39.45^{\mathrm{abc}} \pm 8.57$ & $79.68^{\mathrm{abc}} \pm 44.28$ & $12.9^{\mathrm{a}} \pm 1.52$ \\
\hline Bilar & $9.1^{\text {cde }} \pm 2.81$ & $33.4^{\mathrm{de}} \pm 10.48$ & $31.9^{c d} \pm 9.87$ & $47.73^{\mathrm{cd}} \pm 33.11$ & $12.8^{a} \pm 1.10$ \\
\hline Guindulman & $9.45^{\text {abcde }} \pm 1.98$ & $37.95^{\text {cde }} \pm 13.67$ & $35.65^{\mathrm{bcd}} \pm 9.82$ & $63.94^{\mathrm{bcd}} \pm 54.25$ & $12.14^{\mathrm{a}} \pm 1.21$ \\
\hline Loon & $10.95^{\mathrm{abc}} \pm 2.52$ & $41.65^{\mathrm{abc}} \pm 7.51$ & $41.5^{\mathrm{ab}} \pm 8.38$ & $89.21^{\mathrm{ab}} \pm 58.59$ & $12.44^{a} \pm 1.24$ \\
\hline Mabini & $9.6^{\mathrm{abcde}} \pm 2.12$ & $36.9^{\text {bcde }} \pm 6.56$ & $37.8^{\mathrm{abc}} \pm 7.00$ & $64.35^{\mathrm{bcd}} \pm 27.30$ & $13.14^{\mathrm{a}} \pm 1.07$ \\
\hline Pilar & $8.15^{\mathrm{e}} \pm 1.76$ & $33^{\mathrm{de}} \pm 7.66$ & $30.7^{d} \pm 7.45$ & $40.29^{d} \pm 22.99$ & $11.6^{a} \pm 0.84$ \\
\hline San Miguel & $11.2^{\mathrm{ab}} \pm 1.93$ & $44.85^{\mathrm{a}} \pm 2.69$ & $43.6^{a} \pm 5.06$ & $98.49^{a} \pm 25.96$ & $12.6^{a} \pm 1.90$ \\
\hline
\end{tabular}


Table 2. Continuation

\begin{tabular}{|c|c|c|c|c|c|}
\hline \multirow{2}{*}{ SAMPLING SITES } & \multicolumn{5}{|c|}{ MORPHOLOGICAL TRAITS } \\
\hline & Tail length (inch) & Body Length (inch) & Heart Girth (inch) & Body weight (kg) & No. of teats \\
\hline Talibon & $10.25^{\mathrm{abcd}} \pm 1.93$ & $39.3^{\mathrm{bcd}} \pm 5.64$ & $38.7^{\mathrm{abc}} \pm 4.52$ & $69.13^{\mathrm{abc}} \pm 23.10$ & $12.2^{\mathrm{a}} \pm 0.63$ \\
\hline TOTAL MEAN & $9.78 \pm 2.45$ & $38.07 \pm 8.75$ & $36.91 \pm 8.82$ & $67.29 \pm 41.15$ & $12.38 \pm 1.33$ \\
\hline$p$-value & 0.03246332 & 0.001459358 & 0.002832323 & 0.0022122215 & 0.2703828 \\
\hline
\end{tabular}

Different superscripts in columns indicate that values are significantly different at $0.5 \%$ level of probability $(P<0.005)$

Table 3. Morphological characteristics of native pigs in Bohol Island, Philippines as a function of sex (Mean \pm STD)

\begin{tabular}{ccccc}
\hline & & \multicolumn{2}{c}{ VARIABLES } \\
\hline SEX & Tail length (inch) & Body Length (inch) & Heart Girth (inch) & Body weight $(\mathrm{kg})$ \\
\hline Female & $10.1987^{\mathrm{a}} \pm 2.44861$ & $39.7372^{\mathrm{a}} \pm 8.00800$ & $38.3333^{\mathrm{a}} \pm 7.72820$ & $72.8900^{\mathrm{a}} \pm 38.31549$ \\
Male & $8.2955^{\mathrm{b}} \pm 1.82352$ & $32.1591^{\mathrm{b}} \pm 8.87531$ & $31.8409^{\mathrm{b}} \pm 10.64289$ & $47.4491^{\mathrm{b}} \pm 45.52761$ \\
$\begin{array}{c}\text { Tet Statistic } \\
\text { (Wilcoxon) Value } \\
p \text {-value }\end{array}$ & 341 & 492 & 465.5 & 512.5 \\
& 0.0004741 & 0.0002136 & 0.0009455 & 0.0004684 \\
\hline
\end{tabular}

Means between sexes that differ significantly at $0.1 \%$ level of probability $(P<0.01)$ have different superscripts 
Table 4. Morphological characteristics of native pigs in Bohol Island, Philippines as affected by age (Mean \pm SEM)

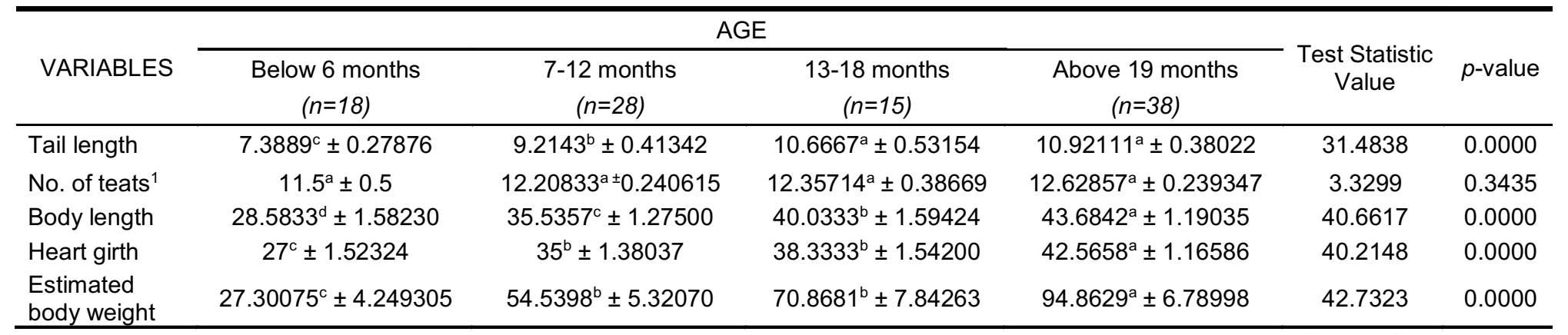

Different superscripts in the means of variables between age groups indicate that values are significantly different at $0.5 \%$ level of probability $(P<0.005)$

- number of animals

1 - number of teats were only accounted to female pigs

Table 5. Correlation analysis of morphological traits between age and sex of native pigs in Bohol Island, Philippines

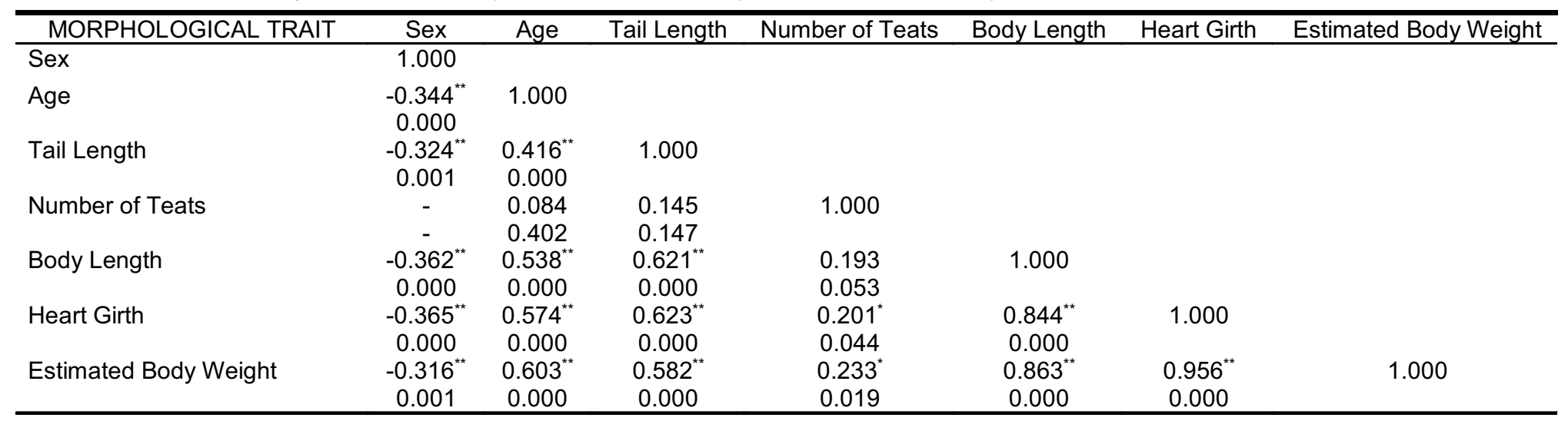

**-Correlation is significant at the 0.01 level First row - correlation coefficient; second row - $p$-value

*-Correlation is significant at the 0.05 level Notes: 1 . Highlighted column uses the Point-Biserial correlation, 2 . Non-highlighted columns use the Pearson r correlation 


\section{Ear Orientation}

In terms of ear orientation, $54 \%$ of the native pigs in Bohol had droopy, $37 \%$ had slightly droopy, and $9 \%$ had erect ears (Table 1). The droopy ear orientation was observed to be highest (90\%) in the municipality of San Miguel, while a high percentage $(60 \%)$ of Alburquerque and Guindulman pigs had slightly droopy ears. Almost a third (30\%) of pigs in Bilar and Guindulman had erect ears (Figure 4). These findings are contrary to Yaetsu et al (1987) who reported that erect ears were common among native pigs in different regions of Bangladesh. However, some of the native pig breeds in other countries such as Taihu and Meishan pigs in China and Large Black pigs from Australia also exhibit drooping ears (The Pig Site 2013). Subalini et al (2010) reported that village pigs could have droopy ears as well, but majority (77\%) had erect ears. It is interesting to note that only $9 \%$ of the native pigs in Bohol exhibited erect ears.

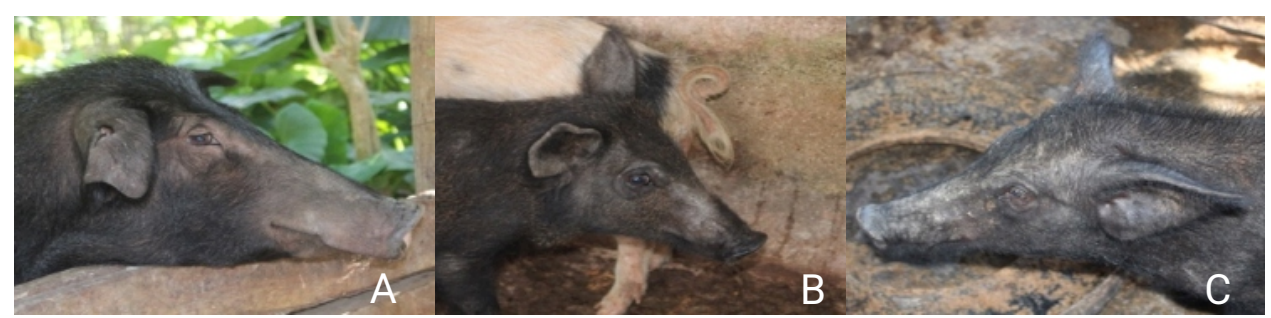

Figure 4. The native pigs in Bohol Island, Philippines showing droopy (A), slightly droopy (B), and erect (C) ear orientation

\section{Quantitative Traits}

\section{Tail Length}

In measuring the tail length, the tail was fully stretched out. Table 2 shows that the native pigs in Bohol had an average tail length of 9.78 inches \pm 2.45 . However, this was significantly different among the towns included in this study. The native pigs in Balilihan had the longest tails (11.3 \pm 3.02 inches) and while the pigs in Pilar had the shortest tails $(8.15 \pm 1.76$ inches). Longer tail lengths were observed in female pigs (10.1987 \pm 2.45 inches) compared to males (8.2955 \pm 1.82 inches) (Table 3). Table 4 shows that tail length increased with age. Layos et al. (2018), however, reported slightly longer average tail lengths of $13.63 \mathrm{~cm}$ in male and 13.55 $\mathrm{cm}$ in female PNPs of Panay and Guimaras Islands. The results of the study contradict with the facts of Philippine native pig described by knowledge base Look Seek Website, in which the male Philippine native pig has a longer tail than its female counterparts with males having a tail length between $57 / 32$ inches and 5 $5 / 8$ inches $(13 \mathrm{~cm}$ and $14 \mathrm{~cm}$ ) and females with $413 / 32$ inches to $413 / 16$ inches $(11 \mathrm{~cm}$ to $12 \mathrm{~cm})$.

\section{Teat Number}

In this study, the mean number of teats of the Bohol native pigs was 12.38 . Majority of the native pigs had 6 pairs of teats (Table 2). The number of teats of 
native pigs across sampling areas in Bohol was not significantly different $(p<$ 0.005). These findings agree with Loffler (1991) who characterized pigs as having six to eight pairs of teats. Schmidt et al. (1936) also mentioned that in the wild pig, animals with eight or twelve teats also occur, but the most frequent was ten teats (5 pairs). Nachtsheim (1924) further explained that higher number of teats is a result of crossbreeding between the Western domestic breeds and the Asian pig breeds, and is an outcome of selection for a greater number of teats in breeding stocks. According to Kurosawa et al (1978) the number of teats is dependent on domestication from wild boar to domesticated pig.

\section{Body Length}

The average body length of the sample pigs was $38.07 \pm 8.75$ inches. Pigs in the municipality of San Miguel had the longest body (44.85 \pm 2.69 inches) while those in Alburquerque had the shortest (30.4 \pm 6.26 inches) (Table 2). Based on sex (Table $3)$, females were observed to have longer (39.74 \pm 8 inches) bodies than the male native pigs (32.16 \pm 8.88 inches). This agrees with Layos et al's (2018) findings that based on sex, female native pigs had a longer $(74.06 \pm 11.32 \mathrm{~cm})$ body than the male native pigs $(68.03 \pm 13.30 \mathrm{~cm})$ in Panay and Guimaras.

\section{Heart Girth}

Native pigs with the largest heart girth (43.6 5.06 inches) were observed in the municipality of San Miguel. Comparing males and females, heart girth was bigger in females (Table 3). The results conformed with Layos et al (2018) who reported a larger hearth girth mean on female PNPs. The study of Javier (2001)revealed that Philippine native pigs had an average heart girth of 27.66 inches: males having an average of 26.5 inches and females, 28.03 inches. Table 4 shows that mean heart girth significantly increased $(P<0.005)$ as the pigs aged.

\section{Estimated Body Weight}

Body weight as a quantitative trait is influenced by both genotype and environment. Other factors, such as directional selective breeding, may contribute in making variations in body size and weight (Jones 1998). The results revealed an overall body weight of $67.29 \pm 41.15 \mathrm{~kg}$, which significantly varied $(p<0.01)$ across pigs in different municipalities. The heaviest $(98.49 \pm 25.96 \mathrm{~kg})$ body weight was found in native pigs from the municipality of San Miguel and the least in Alburquerque (Table 2). Based on sex, it was further observed that female native pigs had higher body weight compared to that of male pigs (Table 3). Table 4 shows the mean estimated body weights of native pigs in Bohol indicating below 6 months, 7 to 12 months, 13 to 18 months, and above 19 months.

A significant correlation (Table 5) was found between sex and age. However, the linear association has negatively weak correlation in terms of sex and positively moderate correlation in terms of age. In general, this means that female native pigs had an advantage over males in all the traits. In terms of age, younger pigs had shorter/smaller values than the older pigs in all traits except in number of teats in females which showed no significant correlation. 


\section{CONCLUSIONS AND RECOMMENDATIONS}

The morphological characteristics of Philippine native pigs among sampling areas in Bohol, Philippines did not greatly vary from each other. Qualitatively, the Philippine native pigs in Bohol Island were predominantly black (73\%) including one wild pig in Bilar, Bohol. In terms of color pattern characteristics, the most prominent was plain color $(91 \%)$ with only $4 \%$ spotted and $5 \%$ patchy. Meanwhile, ear orientation was droopy (54\%), slightly droopy (37\%), and erect (9\%).

On the other hand, quantitative traits revealed an overall body length of $38.07 \pm$ $8.75 \mathrm{in}$, heart girth of $36.9 \pm 8.83 \mathrm{in}$, body weight of $67.29 \pm 41.15 \mathrm{~kg}$, tail length of $9.78 \pm 2.45$, and number of teats $12.38 \pm 1$.33. These had significant differences $(p<$ $0.05)$ across sampling areas and by sex $(p<0.01)$. Generally, females had higher values than males, and trait values showed significant difference $(p<0.05)$ among age groups.

These show that even within an island, PNPs can have phenotypic differences. The phenotypic characteristics gathered in this study can be used in studies differentiating breeds.

For future related studies, it is recommended to increase the number of sampling areas and pig samples, and include other relevant qualitative and quantitative traits for a more comprehensive phenotypic characterization. A study of the pigs' genotypic characteristics should be done to determine if there is any genetic disturbance (mutation or migration) within the population affecting the distribution and variability of their phenotypic traits. Preferably, the feeds and feeding management should be evaluated for possible effect on the phenotypic traits of native pigs.

\section{REFERENCES}

Fang M, Larson G, Soares Ribeiro H, Li N, \& Andersson L. 2009. Contrasting Mode of Evolution at a Coat Color Locus in Wild and Domestic Pigs. PLoS Genet 5(1): e1000341. https://doi.org/10.1371/journal.pgen.1000341

Food and Agriculture Organization Of The United Nations. 2012. Phenotypic characterization of animal genetic resources. FAO Animal Production and Health Guidelines No. 11. Rome (available at http://www.fao.org/ docrep/015/i2686e/i2686e00.pdf).

Food and Fertilizer Technology Center For Asian And Pacific Region. 2017. Empowering small-scale farmers through science and information, FFTC Document Database, http://www.fftc.agnet.org/library.php?func =view\&style=type\&id=20120103110958, retrieved on April 25, 2019.

Giuffra E, Evans G, Törnsten A, Wales R, Day A, \& Looft H. 1999. The belt mutation in pigs is an allele at the dominant white (I/KIT) locus. Mamm. Genome 10, pp. 1132-1136.

Jackson IJ. 1997. Homologous pigmentation mutations in human mouse and other model organisms. Hum. Mol. Genet. 6: pp. 1613-624.

Javier AC. 2001. Weight determination in modern breed of hogs using body measurements. BS thesis. CA. University of the Philippines Los Baños. College, Laguna. 
Jeong HS, Kim DW, Chun SY, Sung S, Kim HJ, Cho S \& Oh SJ. 2014. Native pig and chicken breed database: NPCDB. Asian-Australian Journal of Animal Science, pp. 1394-1398. 1-5. PMCID: PMC4150170. doi: 10.5713/ajas.2014.14059

Johansson M, Ellegren $H$, Marklund L, Gustavsson U, Ringmar-Cederberg E \& Andersson K.1992. The gene for dominant white color in the pig is closely linked to ALB and PDGRFRA on chromosome 8. Genomics 14, pp. 965-969

Jones GF. 1998. Genetic Aspects of Domestication, Common Breeds, And Their Origin. in the Genetics of The Pig. A. (Ed.) Ruvinsky and M. F. Rothschild. pp. 17$50 \mathrm{CAB}$ Int. Oxon, UK

Kijas JM, Moller M, Plastow G \& Andersson L. 2001. A frame shift mutation in MC1R and a high frequency of somatic reversions cause black spotting in pigs. Genetics 158, pp. 779-785

Kijas JM, Wales R, Tornsten A, Chardon P, Moller M \& Andersson L. 1998. Melanocortin receptor 1 (MC1R) mutations and coat color in pigs. Genetics 150, pp. 1177-1185

Klomtong P, Chaweewan K, Phasuk Y \& Duangjinda M. 2015. MC1R, KIT, IGF2, and NR6A1 as markers for genetic differentiation in Thai native, wild boars, and Duroc and Chinese Meishan pigs. Genetics and molecular research: GMR. 14. 12723-12732. 10.4238/2015.October.19.16

Knowledge Base Lookseek (u.d) retrieved from (http://knowledgebase. lookseek.com/Philippine-Native-Pig.html) retrieved on April 29, 2019

Kurosawa Y, Tanaka K \& Inaba H. 1978. The variations of teat number in wild boar population. The Japanese Journal of Swine Husbandry Research, 15(2), 103 10.14899/youton1964.15.103

Layos JK, Nishibori M \& Espina DM. 2018. Morphological and Genetic Characteristics of Philippine Native Pigs (Sus ScrofaDomesticus L.) in Panay and Guimaras Islands, Philippines. Unpublished MS Thesis, Visayas State University, Visca, Baybay City, Leyte, Philippines

Loffler K. 1991. Anatomy and Physiology of Pets. 8. Auflage, Eugen Ulmer Verlag, Stuttgart, Germany

Mason IL. 1996. A World Dictionary of Livestock Breeds, Types and Varieties. Fourth Edition. C.A.B International. p 273

Nachtsheim H. 1924. Studies on the Inheritance in Swine. The inheritance of teat number. Z. indukt. Abstamm. Vererbungsl. 33, pp. 307-311.

Navarra CLF. 1996. Characterization of the Philippine native pig (Sus scrofa L.) based on phenotype, karyotype and protein polymorphism. Philippines Univ. Los Banos, College, Laguna (Philippines).

Pielberg G, Olsson C, Syvänen A \& Andersson L. 2002. Unexpectedly high allelic diversity at the KIT locus causing dominant white color in the domestic pig. Genetics 160, 305-311. PENALBA, F.F. 1993. Native pigs: Performance and potential. Animal Production Technology, 8(1): pp. 2-7.

Sahoo NR. 2012. A monograph on Niang-Megha pig. ICAR-NRC pig, Rani.

Schmidt J, Lauprecht E \& Staubesand H. 1936. Studies on the inheritance of the gestation period birth weight and teat number in the pig. J. Anim. Breed. Genet. 36 pp. $55-100$

Searle AG. 1968. Comparative Genetics of Coat Colour in Mammals. Logos Press, London. 
Morphological Characterization of Native Pigs in Bohol, Philippines

Subalini E, Silva GLLP \& Demetawewa CMB. 2010.Phenotypic Variation in Village and Wild Pigs in Sri Lanka, Postgraduate Institute of Agriculture, University of Peradeniya, Peradeniya. Tropical Agricultural Research 22(3):324 - 329.

The Pig Site. 2013. Breeds Guide. Retrieved on November 27, 2020, fromhttps://www.thepigsite.com/breeds

Yaetsu K, Takashi A, Ikuo O, Katuaki O, Takao N, Yoshizane M, Hasnath MA, Mostofa, KG, Faruque OM \& Majid MA. 1987. Morphological studies of native pigs in Bangladesh. Genetic studies on breed differentiation of the native domestic animals in Bangladesh, 2: pp. 47- 58. 